\title{
Keefektifan Bakteri Asal Lahan Gambut sebagai Agens Pengendalian Penyakit Kresek dan Pupuk Hayati pada Tanaman Padi
}

\section{Effectiveness of Bacterial from Peatlands as Biological Control Agents of Bacterial Leaf Blight Disease and Bio-Fertilizer in Rice}

\author{
Giyanto* dan Ali Nurmansyah \\ Institut Pertanian Bogor, Bogor 16680
}

\begin{abstract}
ABSTRAK
Penggunaan mikrob untuk pengendalian penyakit dan pupuk hayati telah dikembangkan sebagai alternatif bagi pengembangan pertanian ramah lingkungan. Upaya mendapatkan mikrob tersebut terus dilakukan dengan eksplorasi mikrob dari berbagai tipe habitat ekologi untuk mendapatkan yang diinginkan. Lahan gambut diduga mengandung banyak jenis mikrob khususnya bakteri yang berpotensi sebagai agens antagonis sekaligus pupuk hayati yang bermanfaat bagi tanaman. Penelitian ini bertujuan mendapatkan galur bakteri yang berpotensi mengendalikan penyakit kresek atau hawar daun bakteri yang disebabkan oleh Xanthomonas oryzae pv. oryzae sekaligus sebagai pupuk hayati. Tahapan penelitian mencakup pengambilan sampel, isolasi bakteri asal lahan gambut serta uji potensinya sebagai agens hayati terhadap $X$. oryzae pv. oryzae, uji keamanan hayati, karakterisasi galur potensial, uji keefektifan bakteri sebagai agens antagonis sekaligus pupuk hayati in planta. Bakteri yang diisolasi dari tanah hutan gambut dan sawah bekas lahan gambut ialah sebanyak 134 isolat bakteri dan 40 di antaranya memiliki karakteristik morfologi yang berbeda. Sebanyak 14 galur bakteri asal tanah gambut mampu menekan perkembangan $X$. oryzae pv. oryzae. Karakterisasi 14 galur bakteri terhadap uji hypersensitive response, hemolisis agar-agar darah, kemampuan menambat nitrogen, siderofor yang dihasilkan, pelarut fosfat serta degradasi selulosa menghasilkan empat galur bakteri potensial. Keempat galur ini tidak berpotensi sebagai patogen terhadap tanaman maupun mamalia serta memiliki karakter sebagai pupuk hayati. Uji in planta empat galur bakteri ini menunjukkan bahwa bakteri tersebut mampu menekan keparahan penyakit hawar daun pada padi serta meningkatkan pertumbuhan padi pada fase vegetatif.
\end{abstract}

Kata kunci: agens antagonis, antibiosis, hawar daun, hypersensitive response (HR), Xanthomonas oryzae pv. oryzae

\begin{abstract}
The use of microbes for disease control and biological fertilizers has been developed as an alternative to the development of environmentally friendly agriculture. Exploration of microbes from various types of ecological habitats is continuously being carried out to obtain the potential microbes. Peatlands are thought to contain many types of microbes, especially bacteria that may play a role as antagonistic agents as well as biological fertilizers that are beneficial to plants. This study aimed to obtain bacterial strains that have the potential to control bacterial leaf blight (BLB) diseases on rice caused by Xanthomonas oryzae pv. oryzae as well as biological fertilizer. Research methodologies included sampling, isolating bacteria from peatlands and testing their potential as biological agents against $X$. oryzae pv. oryzae, biosafety tests,
\end{abstract}

*Alamat penulis korespondensi: Departemen Proteksi Tanaman, Fakultas Pertanian, Institut Pertanian Bogor. Kampus IPB Darmaga, Jalan Kamper, Bogor 16680.

Tel: 0251-8629364, Faks: 0251-8629362; Surel: giyanto2@yahoo.com 
characterization of potential strains, test of the effectiveness of bacteria as antagonistic agents as well as biological fertilizers in planta. As many as 134 bacteria isolates were isolated from peat forest soil and former paddy fields and 40 of them showed different morphological characteristics. A total of 14 bacterial strains from peat soil were able to suppress the development of $X$. oryzae pv. oryzae. Characterization of 14 bacterial strains against the hypersensitive response (HR) test, blood agar hemolysis, nitrogen fixing ability, the resulting siderophore, phosphate solvent and cellulose degradation resulted in four potential bacterial strains. They have no potential as a pathogen for plants or mammals and have the character of a biological fertilizer. The in planta test of these four bacterial strains showed that these bacteria were able to reduce the severity of BLB disease in rice and increase rice growth in the vegetative phase.

Key words: antagonist agents, antibiosis, hypersensitive response (HR), leaf blight, Xanthomonas oryzae pv. oryzae

\section{PENDAHULUAN}

Indonesia sebagai negera megabiodiversitas ke-2 setelah Brasil memiliki keanekaragaman hayati yang tinggi. Berbagai tipe ekologi di Indonesia diduga memiliki keragaman flora, fauna maupun mikrob yang berpeluang untuk dieksplorasi bagi kemanfaatan bersama. Salah satu tipe ekologi yang dimiliki Indonesia adalah lahan gambut. Indonesia memiliki $16.5-27.0$ juta ha lahan gambut, terbesar di Asia dan nomor empat di dunia (Sorensen 1993). Data lahan gambut di Indonesia berdasarkan pada BBSDLP tercatat seluas 14905574 ha pada tahun 2011 dan yang terluas terdapat di Pulau Sumatera, yaitu 6436649 ha (Ritung et al. 2011).

Upaya swasembada beras terus digalakkan dengan pencetakan sawah baru untuk pertanaman padi terutama pada lahan gambut. Hal ini tidak terlepas dari potensi besar luasan lahan gambut yang dimiliki Indonesia. Budi daya padi pada sawah bekas lahan gambut tidak terlepas dari cekaman abiotik maupun biotik. Salah satu cekaman biotik ialah serangan $X$. oryzae pv. oryzae pada berbagai stadium pertumbuhan padi yang dapat menyebabkan penyakit hawar daun bakteri (HDB) atau sering disebut juga sebagai penyakit kresek. Suparyono et al. (2004) melaporkan bahwa penyakit kresek dapat menyebabkan kehilangan hasil hingga 35.8\%.

Upaya pengendalian penyakit kresek mencakup perakitan varietas tahan, penggunaan benih bebas patogen, teknik budi daya, pengendalian hayati menggunakan agens antagonis, serta penggunaan bakterisida.
Penggunaan varietas tahan merupakan teknik pengendalian yang mudah, murah, efektif, serta diterima secara luas oleh petani, tetapi ketahanan suatu varietas mudah dipatahkan oleh munculnya patotipe baru dari X. oryzae pv. oryzae. Penggunaan bakterisida telah dilarang berdasarkan Peraturan Menteri Pertanian Republik Indonesia No. 39/Permentan/ SR.330/7/2015 tentang Pendaftaran Pestisida karena dikhawatirkan akan memicu resistensi bakteri terhadap antibiotika. Dengan demikian pengendalian hayati menggunakan agens antagonis memiliki peluang untuk dikembangkan sebagai teknik pengendalian yang berkelanjutan dan ramah lingkungan.

Upaya eksplorasi agens antagonis dari lahan gambut untuk pengendalian penyakit kresek penting dilakukan dalam rangka mendukung kebijakan ekstensifikasi pertanian padi pada lahan gambut. Pratiwi et al. (2018) berhasil mengisolasi dan menentukan karakteristik berbagai jenis bakteri di lahan perkebunan sawit pada lahan gambut di Tanjung Jabung Timur, Provinsi Jambi. Bakteri tersebut memiliki potensi sebagai pupuk hayati pemacu pertumbuhan tanaman.

Penelitian terkait eksplorasi agens antagonis dari lahan gambut untuk mengendalikan penyakit kresek pada pertanaman padi lahan gambut belum banyak dilakukan. Oleh karena itu, penelitian ini ditujukan untuk mendapatkan bakteri asal lahan gambut yang berpotensi sebagai agens antagonis untuk mengendalikan penyakit kresek yang disebabkan oleh $X$. oryzae pv. oryzae, sekaligus sebagai pupuk hayati pada tanaman padi. 


\section{BAHAN DAN METODE}

\section{Pengambilan Sampel Tanah dan Isolasi Bakteri Asal Tanah Gambut}

Sampel tanah diambil dari hutan gambut di PT. Global Alam Lestari dan sawah lahan gambut milik petani yang berada di Kabupaten Musi Banyuasin, Provinsi Sumatera Selatan pada tanggal 8-13 September 2019. Berbagai macam jenis sampel tanah diambil dari hutan gambut alami $\left(104^{\circ} 12^{\prime} 45.688^{\prime \prime} \mathrm{E} ; 2^{\circ} 2^{\prime}\right.$ $\left.38.951^{\prime \prime} \mathrm{S}\right)$, hutan gambut terbakar $\left(104^{\circ} 3\right.$ ' 37.649 " E; $2^{\circ} 2$ ' 10.565 " S), hutan gambut terbakar yang direboisasi (104 ${ }^{\circ} 5^{\prime} 45.589^{\prime \prime} \mathrm{E} ; 2^{\circ}$ 5' 1.306" S), sawah bekas hutan gambut yang digunakan sekaligus sebagai tambak (104 ${ }^{\circ} 44^{\prime}$ 35.761" E; $2^{\circ} 15^{\prime} 18.176$ " S), dan sawah lahan gambut bukan tambak $\left(104^{\circ} 45^{\prime} 7.913\right.$ " E; $2^{\circ}$ 15 ' 18.072" S). Proses pengambilan sampel tanah dilakukan dengan menggunakan bor gambut model Eijkelkamp pada kedalaman $\pm 50 \mathrm{~cm}$. Bor diangkat dan tanah yang terdapat di dalam bor dengan volume $\pm 500 \mathrm{~cm}^{3}$ dibagi pada tiga kedalaman $(1-15,16-30$, dan 31-45 $\mathrm{cm})$. Dalam satu jenis sampel tanah dilakukan pengeboran pada tiga titik dan tanah dari setiap kedalaman pada bor gambut dikompositkan dan diambil $200 \mathrm{~g}$ untuk isolasi bakteri. Semua sampel tanah yang diambil dari lapangan dimasukkan dalam boks pendingin yang diisi dengan gel beku dan setelah sampai di laboratorium disimpan pada suhu $5{ }^{\circ} \mathrm{C}$ sampai dilakukan proses isolasi bakteri.

Bakteri asal tanah gambut diisolasi dengan teknik pengenceran berseri dari $10^{\circ}$ sampai $10^{7}$ dan pencawanan pada medium agar-agar nutrien (AN) $10 \%$ pH 5.0. Sebanyak $50 \mu \mathrm{L}$ dari setiap pengenceran disebar pada medium $\mathrm{AN}$ dan diinkubasikan pada suhu ruang $\left(30^{\circ} \mathrm{C}\right)$ selama lima hari. Koloni bakteri yang berbeda dari masing-masing sampel tanah dimurnikan lalu disimpan dalam larutan gliserol 20\%, dan disimpan pada suhu $-30{ }^{\circ} \mathrm{C}$ sebagai biakan murni.

\section{Uji Bakteri Asal Tanah Gambut sebagai Agens Antagonis Xanthomonas oryzae pv. oryzae}

Bakteri asal tanah gambut diuji sebagai agens antagonis terhadap $X$. oryzae pv. oryzae dengan teknik plate diffusion assay. Bakteri patogen $X$. oryzae pv. oryzae patotipe III yang digunakan berasal dari koleksi biakan Balai Besar Penelitian Tanaman Padi, Subang, Jawa Barat. Xanthomonas oryzae pv. oryzae dibiakkan pada medium Wakimoto cair selama 36 jam dengan konsentrasi $10^{8} \mathrm{cfu} \mathrm{mL}^{-1}$. Sebanyak $100 \mathrm{~mL}$ disebarkan pada medium AN dan kertas saring steril berdiameter $5 \mathrm{~mm}$ yang diletakkan di atas permukaanya. Pada kertas saring tersebut selanjutnya diteteskan $20 \mu \mathrm{L}$ suspensi bakteri asal tanah lahan gambut $\left(10^{8} \mathrm{cfu} \mathrm{mL}^{-1}\right)$ yang dibiakkan pada medium nutrien cair selama 24 jam. Cawan petri yang telah diinokulasi baik bakteri patogen maupun agens hayati tersebut diinkubasikan pada suhu ruang selama tujuh hari. Pengamatan kualitatif dilakukan terhadap ada tidaknya zona bening di sekitar kertas saring.

\section{Uji Hipersensitif}

Uji hipersensitif dilakukan sebagai proses lanjutan penapisan galur bakteri asal tanah gambut. Suspensi bakteri sebanyak $100 \mu \mathrm{L}$ dengan kerapatan $10^{8} \mathrm{cfu} \mathrm{mL}^{-1}$ diinfiltrasikan pada daun tembakau var. White Burley menggunakan jarum suntik. Pengamatan dilakukan 24-48 jam terhadap gejala nekrotik pada daun yang diinfiltrasikan suspensi bakteri (Schaad et al. 2001).

\section{Uji Hemolisis Agar-Agar Darah}

Bakteri asal tanah gambut digoreskan pada medium agar-agar darah serta diinkubasikan pada suhu $30^{\circ} \mathrm{C}$ selama $2-4$ hari. Uji hemolisis positif diindikasikan oleh zona bening di sekitar koloni bakteri.

\section{Potensi Bakteri Terpilih Sebagai Pupuk Hayati}

Pengujian bakteri asal tanah gambut yang berpotensi sebagai pupuk hayati mencakup kemampuan bakteri dalam menambat $\mathrm{N}$, menghasilkan siderofor, melarutkan $\mathrm{P}$, dan menguraikan selulosa.

Kemampuan Bakteri dalam Menambat

N. Metode yang digunakan untuk mengetahui kemampuan bakteri asal tanah gambut dalam menambat $\mathrm{N}$ menggunakan metode Kifle dan Laing (2016). Pengujian dilakukan 
pada medium bebas $\mathrm{N}$ yang mengandung $20 \mathrm{~g}$ manitol sebagai sumber karbon, $0.2 \mathrm{~g}$ $\mathrm{K}_{2} \mathrm{HPO}_{4}, 0.2 \mathrm{~g} \mathrm{NaCl}, 0.2 \mathrm{~g} \mathrm{MgSO}_{4} \cdot 7 \mathrm{H}_{2} \mathrm{O}$, $0.1 \mathrm{~g} \mathrm{~K}_{2} \mathrm{SO}_{4}, 5.0 \mathrm{~g} \mathrm{CaCO}, 20 \mathrm{~g}$ agar-agar, dan $1 \mathrm{~L}$ air suling. Suspensi bakteri asal tanah gambut digoreskan pada medium dan diinkubasi pada $30{ }^{\circ} \mathrm{C}$ selama empat hari. Bakteri yang tumbuh mengindikasikan kemampuannya dalam menambat N.

Kemampuan Bakteri dalam Menghasilkan Siderofor. Analisis kemampuan bakteri menghasilkan siderofor menggunakan medium agar-agar chrome azurol sulfonat. Perubahan warna medium dari biru menjadi oranye, ungu atau magenta di sekitar koloni bakteri menunjukkan kemampuan bakteri menghasilkan siderofor (Milagres et al. 1999).

Kemampuan Bakteri dalam Melarutkan

P. Produksi enzim fosfatase untuk melarutkan $\mathrm{P}$ oleh bakteri asal tanah gambut dideteksi menggunakan medium agar-agar Pikovskaya. Adanya zona bening di sekitar bakteri mengindikasikan adanya kemampuan isolat bakteri dalam melarutkan P (Karpagam dan Nagalakshmi 2014).

Kemampuan Bakteri dalam Mendegradasi Selulosa. Uji degradasi selulosa oleh bakteri menggunakan medium agar-agar carboxymethyl cellulose (CMC) yang mengandung $2.5 \mathrm{~g} \mathrm{NaNO}_{3}, 0.2 \mathrm{~g} \mathrm{MgSO}_{4}$, $0.2 \mathrm{~g} \mathrm{NaCl}, 0.1 \mathrm{~g} \mathrm{CaCl}_{2} \cdot 6 \mathrm{H}_{2} \mathrm{O}, 20 \mathrm{~g}$ agaragar, $1 \mathrm{~g} \mathrm{CMC}$, dan $1 \mathrm{~L}$ air suling. Suspensi bakteri diinokulasikan pada agar-agar $\mathrm{CMC}$, kemudian diinkunbasikan pada suhu $30{ }^{\circ} \mathrm{C}$ selama empat hari. Selanjutnya medium yang telah ditumbuhi oleh bakteri digenangi dengan $5 \mathrm{~mL}$ larutan pewarna Congo Red 0.1\% selama 15 menit. Larutan pewarna dibuang dan permukaan medium agar-agar dibilas dengan larutan $\mathrm{NaCl} 1 \mathrm{M}$. Adanya zona bening di sekitar koloni bakteri mengindikasikan aktivitas selulolitik bakteri (Gupta et al. 2012).

Kemampuan Isolat Bakteri Terpilih dalam Menekan Serangan Xanthomonas oryzae pv. oryzae

Galur bakteri terpilih yang memiliki kemampuan antagonis terhadap $X$. oryzae pv. oryzae serta uji HR maupun hemolisis agar- agar darah negatif diuji lanjut kemampuannya untuk menekan perkembangan serangan $X$. oryzae pv. oryzae. Tanaman padi 'Vietnam' (nama lokal yang diberikan oleh petani di Kabupaten Musi Banyuasin) ditanam dalam ember (tinggi $15 \mathrm{~cm}$ dan diameter $25 \mathrm{~cm}$ ) yang berisi tanah sawah dan dipelihara sampai masa akhir vegetatif (48 HST). Inokulasi $X$. oryzae pv oryzae dilakukan dengan cara menggunting ujung daun padi menggunakan gunting yang dicelupkan dalam suspensi bakteri $X$. oryzae pv. oryzae pada kepadatan $10^{9} \mathrm{cfu} \mathrm{mL}^{-1}$. Daun yang telah digunting tersebut kemudian disemprot dengan suspensi bakteri asal tanah gambut terpilih $\left(10^{8} \mathrm{cfu} \mathrm{mL}^{-1}\right)$ secara merata. Selanjutnya tanaman padi disungkup dengan plastik bening (tinggi $100 \mathrm{~cm}$ dan diameter $40 \mathrm{~cm}$ ) selama 24 jam. Aplikasi bakteri agens hayati diulang selama dua minggu, masing-masing dilakukan satu kali aplikasi dalam seminggu. Aplikasi ini dilakukan pada pukul 16.00.

Penelitian ini dirancang menggunakan rancangan acak kelompok. Galur bakteri asal tanah gambut diuji pada 30 rumpun padi dan diulang lima kali. Pengamatan dilakukan terhadap tingkat keparahan gejala serangan yang dilakukan selama tiga minggu berturutturut menggunakan sistem skor (Tabel 1). Pengolahan data dilakukan dengan analisis ragam. Pengujian terhadap nilai tengah dilakukan dengan menggunakan uji Tukey pada taraf 5\%.

Keparahan penyakit (KP) dihitung menggunakan standard evaluation system for rice (IRRI 2014) dengan menggunakan rumus:

Tabel 1 Sistem skor untuk menghitung keparahan gejala serangan Xanthomonas oryzae pv. oryzae pada tanaman padi

\begin{tabular}{ll}
\hline $\begin{array}{l}\text { Tingkat infeksi pada luas } \\
\text { daun }(\%)\end{array}$ & Skor \\
\hline Tidak ada infeksi & 0 \\
Kurang dari 1 & 1 \\
$1-5$ & 3 \\
$6-25$ & 5 \\
$26-50$ & 7 \\
$51-100$ & 9 \\
\hline
\end{tabular}




$$
\mathrm{KP}=\frac{\sum_{\mathrm{i}=0}^{i}\left(\mathrm{n}_{i} \times \mathrm{v}_{i}\right)}{\mathrm{N} \times \mathrm{V}} \times 100 \% \text {, dengan }
$$

ni, jumlah tanaman dengan skor ke-i; $\mathrm{v}_{\mathrm{i}}$, nilai skor penyakit dari $\mathrm{I}=0,1,2$ sampai i t-skor tertinggi; $\mathrm{N}$, jumlah tanaman yang diamati; dan $\mathrm{V}$, skor tertinggi.

\section{Kemampuan Galur Bakteri Asal Gambut Terpilih untuk Meningkatkan Pertumbuhan Tanaman}

Karakterisasi fungsional terhadap bibit padi dilakukan secara langsung dengan mengamati panjang tajuk dan akar tanaman padi. Benih padi 'Vietnam' ditanam dalam gelas plastik (diameter $7 \mathrm{~cm}$, tinggi $10 \mathrm{~cm}$ ) berisi medium zeolit. Setiap medium tanam disiram dengan $15 \mathrm{~mL}$ suspensi bakteri $10^{8}$ cfu $\mathrm{mL}^{-1}$. Selanjutnya setiap medium ditanami satu benih padi dan disiram air steril supaya tetap basah setiap hari.

Percobaan ini disusun dalam rancangan acak kelompok dengan lima ulangan. Setiap unit percobaan terdiri atas 30 bibit padi. Tinggi bibit dan panjang akar diukur pada saat bibit berumur 12 dan 48 hari setelah tanam. Pengolahan data dilakukan dengan analisis ragam. Pengujian terhadap nilai tengah dilakukan dengan uji Tukey pada taraf 5\%.

\section{HASIL}

\section{Bakteri Asal Tanah Gambut}

Sebanyak 134 galur bakteri berhasil diisolasi dari lahan tanah gambut di hutan ataupun sawah yang memiliki kisaran $\mathrm{pH}$ 2.56.4 (data tidak dipublikasikan). Galur bakteri dipilih berdasarkan pada lokasi asal sampel dan perbedaan karakter koloni, serta diberikan kode galur BG001 hingga BG134.

\section{Potensi Bakteri Asal Gambut sebagai Agens Antagonis dan Pupuk Hayati}

Sebanyak 40 galur bakteri yang mewakili berbagai sampel tanah serta perbedaan fenotipe koloni dipilih untuk uji potensi agens antagonis dan pupuk hayati. Sebanyak 14 galur bakteri mempunyai kemampuan menekan pertumbuhan $X$. oryzae pv. oryzae yang diindikasikan oleh adanya zona bening di sekitar kertas saring (Gambar 1). Beberapa karakter bakteri asal tanah gambut menunjukkan pertumbuhan hanya pada permukaan kertas saring dan tidak menunjukkan zona bening (Gambar 1a), pertumbuhan di atas dan di sekitar kertas saring menunjukkan zona bening (Gambar 1b), serta pertumbuhan melebar di sekitar kertas saring menunjukkan zona bening (Gambar 1c). Terbentuknya zona bening di sekitar kertas saring mengindikasikan bakteri calon agens hayati yang diteteskan pada kertas saring mampu tumbuh dan menghasilkan senyawa bioaktif yang menekan pertumbuhan bakteri patogen yang ada di sekitar kertas saring.

Uji lanjut 14 galur bakteri asal tanah gambut menunjukkan 10 galur yang bereaksi positif terhadap uji HR dan atau hemolisis agar-agar darah. Dengan demikian 10 galur tersebut tidak dapat digunakan pada uji lanjut karena berpotensi sebagai patogen tumbuhan dan atau mamalia. Empat bakteri asal gambut (BG003, BG010, BG011, dan BG013) berpotensi dan aman dikembangkan sebagai agens antagonis untuk pengendalian penyakit kresek pada padi. Empat bakteri ini memiliki kemampuan menambat $\mathrm{N}$, melarutkan $\mathrm{P}$, menghasilkan siderofor, dan mendegradasi selulosa (Tabel 2).

\section{Keefektifan Bakteri Asal Tanah Gambut dalam Pengendalian Penyakit Kresek}

Galur bakteri BG003, BG010, BG011, dan BG013 yang diuji keefektifannya dalam mengendalikan penyakit kresek in planta, belum tampak berperan dalam mengendalikan penyakit tersebut jika dibandingkan dengan kontrol pada pengamatan satu minggu setelah inokulasi (Tabel 2). Penyakit kresek oleh bakteri asal gambut terlihat nyata penekanannya jika dibandingkan dengan kontrol pada pengamatan minggu ke-2 dan 3 setelah inokulasi. Pada minggu ke-3 setelah inokulasi, galur BG003 dan BG010 dapat menekan penyakit kresek masing masing sebesar $37 \%$ dan $42 \%$ dibandingkan dengan kontrol (Tabel 3). Secara visual tanaman padi yang diberi perlakuan bakteri asal tanah 


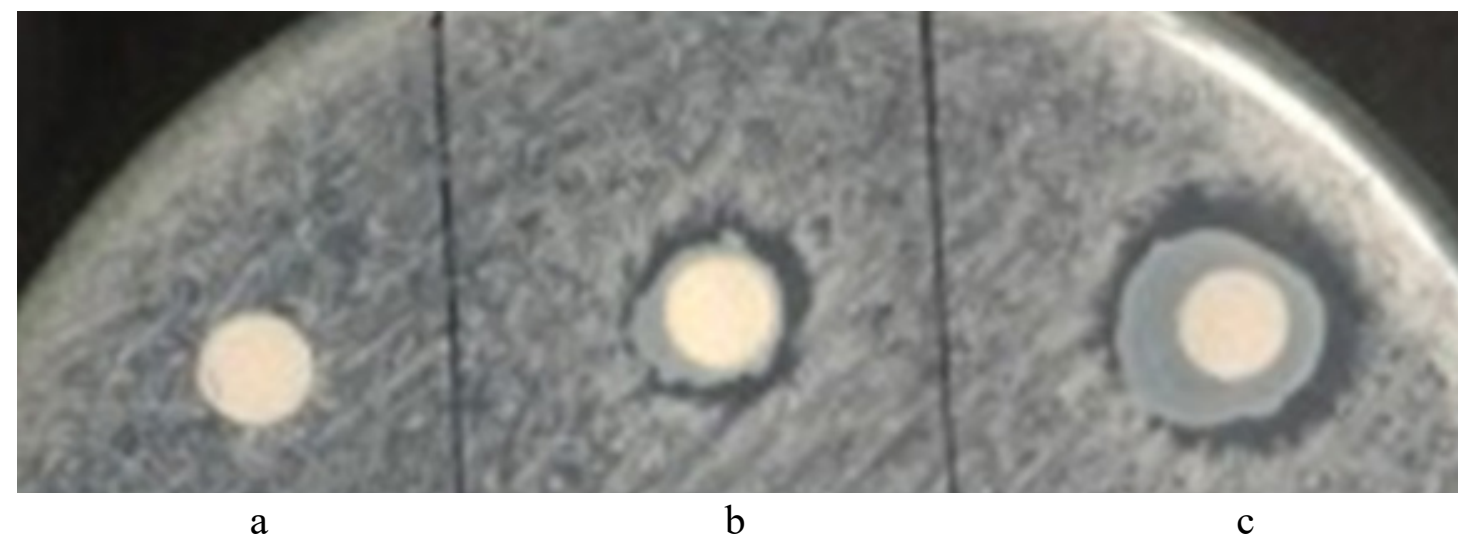

Gambar 1 Penghambatan pertumbuhan Xanthomonas oryzae pv. oryzae oleh bakteri asal tanah gambut. a, Bakteri asal gambut dengan pertumbuhan hanya pada permukaan kertas saring dan tidak menunjukkan zona bening; $b$, Bakteri asal gambut dengan pertumbuhan di atas dan di sekitar kertas saring serta menunjukkan zona bening; dan c, Bakteri asal gambut dengan pertumbuhan di atas dan melebar di sekitar kertas saring serta menunjukkan zona bening.

Tabel 2 Karakteristik bakteri asal tanah gambut sebagai kandidat agens antagonis dan pupuk hayati

\begin{tabular}{|c|c|c|c|c|c|c|c|c|}
\hline \multirow{2}{*}{ Bakteri } & \multirow{2}{*}{ Antibiosis* } & \multirow{2}{*}{ Gram } & \multicolumn{2}{|c|}{ Uji Patogenisitas } & \multicolumn{4}{|c|}{ Karakteristik sebagai pupuk hayati } \\
\hline & & & RH & $\mathrm{H}$ & Fiksasi N & Siderofor & Pelarut $\mathrm{P}$ & Selulolitik \\
\hline BG003 & + & Positif & - & - & + & ++ & + & + \\
\hline BG004 & + & Positif & - & + & - & + & - & + \\
\hline BG010 & + & Negatif & - & - & + & ++ & + & + \\
\hline BG011 & + & Negatif & - & - & + & ++ & + & + \\
\hline BG012 & + & Negatif & - & + & + & ++ & + & + \\
\hline BG013 & + & Negatif & - & - & + & ++ & - & + \\
\hline BG014 & + & Positif & - & + & + & ++ & - & - \\
\hline BG015 & + & Negatif & - & + & + & ++ & - & - \\
\hline BG016 & + & Negatif & - & + & + & ++ & - & - \\
\hline BG033 & + & Positif & - & + & + & - & + & + \\
\hline BG051 & + & Positif & + & - & + & ++ & + & + \\
\hline BG064 & + & Negatif & - & + & + & ++ & + & - \\
\hline BG085 & + & Negatif & - & + & + & ++ & + & + \\
\hline BG119 & + & Positif & - & + & - & - & - & - \\
\hline
\end{tabular}

Keterangan: *, terhadap Xanthomonas oryzae pv. oryzae; RH, Reaksi hipersensitif; H, Hemolisis; +, aktivitas atau reaksi positif; ++, aktivitas atau reaksi lebih kuat; dan -, aktivitas atau reaksi negatif.

Tabel 3 Intensitas penyakit kresek pada perlakuan empat galur bakteri asal gambut

\begin{tabular}{lccc}
\hline \multirow{2}{*}{ Bakteri } & \multicolumn{3}{c}{ Keparahan penyakit kresek (\%) } \\
& 1 & 2 & 3 \\
\cline { 2 - 4 } & $11.85 \mathrm{a}$ & $19.18 \mathrm{~b}$ & $24.22 \mathrm{c}$ \\
BG003 & $10.44 \mathrm{a}$ & $19.69 \mathrm{~b}$ & $27.07 \mathrm{c}$ \\
BG010 & $12.67 \mathrm{a}$ & $35.26 \mathrm{a}$ & $51.70 \mathrm{~b}$ \\
BG011 & $11.78 \mathrm{a}$ & $24.22 \mathrm{~b}$ & $60.29 \mathrm{ab}$ \\
BG013 & $12.15 \mathrm{a}$ & $38.59 \mathrm{a}$ & $64.59 \mathrm{a}$ \\
Kontrol & $12.15 g u$ ke- \\
\hline
\end{tabular}

Angka pada kolom tiap peubah pengamatan yang diikuti huruf sama tidak berbeda nyata menurut uji Tukey pada $\alpha 5 \%$.
Tabel 4 Tinggi tajuk dan panjang akar padi pada perlakuan empat galur bakteri asal gambut

\begin{tabular}{lrrrrr}
\hline \multirow{2}{*}{ Bakteri } & \multicolumn{2}{c}{ Tinggi tajuk } & & \multicolumn{2}{c}{ Panjang akar } \\
\cline { 2 - 3 } \cline { 5 - 6 } BG003 & 12 HST & 48 HST & & 12 HST & 48 HST \\
\cline { 2 - 3 } BG010 & $17.00 \mathrm{a}$ & $38.70 \mathrm{a}$ & & $10.10 \mathrm{a}$ & $17.20 \mathrm{ab}$ \\
BG011 & $17.20 \mathrm{a}$ & $39.50 \mathrm{a}$ & & $10.52 \mathrm{a}$ & $18.90 \mathrm{a}$ \\
BG013 & $18.00 \mathrm{a}$ & $35.70 \mathrm{a}$ & & $10.92 \mathrm{a}$ & $13.30 \mathrm{a}$ \\
Kontrol & $17.00 \mathrm{a}$ & $25.40 \mathrm{~b}$ & & $8.40 \mathrm{a}$ & $13.00 \mathrm{~b}$ \\
\hline
\end{tabular}

Angka pada kolom tiap peubah pengamatan yang diikuti huruf sama tidak berbeda nyata menurut uji Tukey pada $\alpha$ 5\%. HST, hari setelah tanam 
gambut tampak lebih baik dibandingkan dengan kontrol (Gambar 2).

\section{Keefektifan Bakteri Asal Tanah Gambut sebagai Pupuk Hayati}

Empat galur bakteri asal gambut yang diuji tidak berpengaruh terhadap tinggi tajuk bibit padi dan panjang akar pada 12 hari setelah tanam (HST). Pengaruhnya terlihat pada pengamatan 48 HST. Tinggi tanaman padi nyata berbeda dengan kontrol, namun panjang akarnya hanya nyata ditunjukkan oleh galur BG010 dan BG013 (Tabel 4). Pengamatan kualitatif menunjukkan bahwa perakaran tanaman padi yang diberi perlakuan bakteri asal gambut lebih banyak dibandingkan dengan kontrol (Gambar 3).

\section{PEMBAHASAN}

Menjadi pengetahuan umum bahwa kandungan bahan organik yang tinggi bertanggung jawab terhadap kondisi lahan gambut yang masam, kandungan nutrisi, serta oksigen terlarut yang rendah berakibat pada laju dekomposisi atau mineralisasi bahan organik yang lambat. Namun dalam kondisi demikian lahan gambut merupakan habitat dari banyak jenis flora, fauna, maupun mikrob dengan proporsi spesies endemik yang memiliki potensi tinggi dalam bidang kesehatan dan manfaat lainnya bagi manusia (UNDP 2006; Pankratov et al. 2011). Hal ini merupakan tantangan tersendiri bagaimana memanfaatkan potensi lahan gambut yang baik. Salah satu komponen pada ekosistem gambut yang berperan penting dalam proses ekologi ialah bakteri.

Pemanfaatan bakteri dari lahan gambut dengan tipe ekologi unik untuk pengendalian penyakit tanaman dan pupuk hayati masih terbatas. Pada sisi lain pemanfaatan lahan gambut untuk pertanian tanaman pangan khususnya padi semakin digalakkan. Hal ini menjadi latarbelakang dilakukannya penelitian ini. Banyak isolat bakteri yang tumbuh pada medium AN 10\%, pH 5.0. Kondisi $\mathrm{pH}$ medium yang masam dimaksudkan untuk menyesuaikan dengan asal bakteri dari lahan a

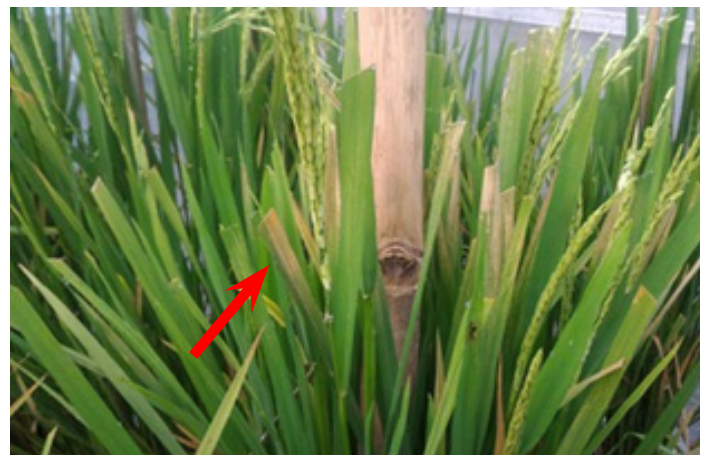

b

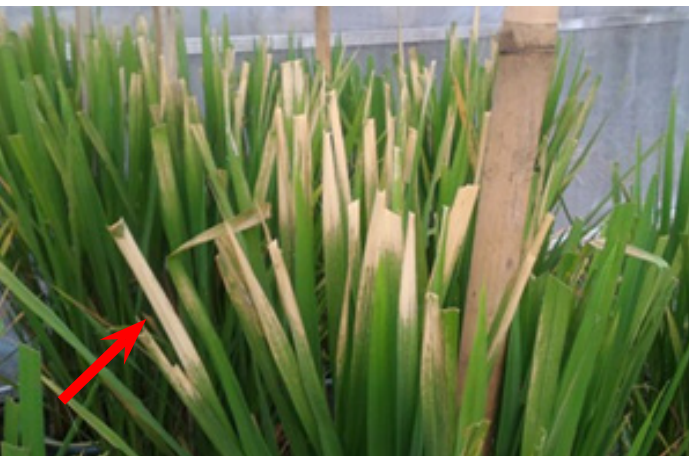

Gambar 2 Gejala penyakit kresek (tanda panah) pada tiga minggu setelah inokulasi: a, Bakteri BG003; dan b, Kontrol.



a

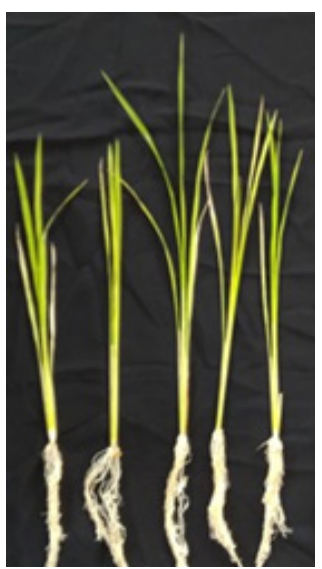

b
Gambar 3 Penampakan akar bibit padi pada umur 48 hari setelah inokulasi: a, Bakteri asal tanah gambut; dan b, Kontrol.

gambut yang juga bersifat masam. Galur bakteri yang diperoleh memiliki karakter morfologi bentuk koloni, ukuran, warna, dan bau yang bermacam macam (data tidak dipublikasikan).

Bakteri diketahui merupakan mikroorganisme yang beragam dalam karakter fisiologi yang mampu hidup dalam kondisi aerob maupun anaerob, pada suhu panas, 
kondisi sangat masam, kondisi dengan kandungan logam yang tinggi, maupun kondisi lain yang belum ditemukan mampu dihuni oleh kelompok nonbakteri. Pendekatan biologi molekuler melaporkan bahwa pada $1 \mathrm{~g}$ tanah gambut mengandung $10^{4} \mathrm{sel}$ bakteri serta mengandung $10^{9}$ sel mikrob total (RosellóMora dan Amann 2001).

Pengetahuan tentang peran penting mikrob dalam proses ekosistem merupakan kunci pengelolaan suatu ekologi. Perannya tidak hanya dalam rangka konservasi in situ, tetapi juga dengan sifat atau karaktersistik khusus bakteri yang mampu hidup dalam kondisi lahan gambut dapat dimanfaatkan. Kemampuannya sebagai agens hayati, pemacu pertumbuhan tanaman, ataupun proses dekomposisi bahan organik dilaporkan oleh Mace et al. (2012).

Sebanyak 14 galur bakteri memiliki sifat antibiosis terhadap $X$. oryzae pv. oryzae. Hal ini menunjukkan terdapat potensi galur bakteri sebagai agens hayati untuk pengendalian penyakit kresek pada padi. Uji keefektifan menunjukkan terdapat dua galur bakteri (BG003 dan BG010) yang dapat mengendalikan penyakit kresek (Gambar 2 dan Tabel 3). Hoa et al. (2012) melaporkan galur-galur aktinomiset mampu menghambat 10 ras $X$. oryzae pv. oryzae. Salah satu di antaranya ialah Streptomyces virginiae yang tidak bersifat fitotoksik terhadap padi.

Selain sebagai agens hayati, bakteri BG003, BG010, dan BG011 memiliki kemampuan menekan $X$. oryzae pv. oryzae, menghasilkan siderofor, melarutkan $\mathrm{P}$, dan bersifat selulolitik. Galur BG013 tidak melarutkan P, tetapi dapat menambat $\mathrm{N}$, menghasilkan siderofor, dan mendegradasi selulosa. Uji in planta dari keempat bakteri tersebut juga menunjukkan kemampuan membantu pertumbuhan tanaman padi (Gambar 3 dan Tabel 4).

Bakteri penambat $\mathrm{N}$ mengubah $\mathrm{N}_{2}$ di udara menjadi amonia $\left(\mathrm{NH}_{3}\right)$ yang kemudian diubah menjadi asam amino yang akan digunakan oleh tanaman untuk tumbuh dan berkembang. Keberadaan bakteri pelarut $\mathrm{P}$ penting bagi pertumbuhan tanaman karena membantu ketersediaan $\mathrm{P}$ terlarut di tanah. Jumlah $\mathrm{P}$ terlarut sangat rendah karena diikat dalam bentuk Fe-P dan Al-P pada tanah masam atau $\mathrm{Ca}_{3}\left(\mathrm{PO}_{4}\right)_{2}$ pada tanah basa. Mekanisme pelarutan $\mathrm{P}$ erat hubungannya dengan sekresi asam organik oleh bakteri. Asam organik tersebut mengkelat kation ( $\mathrm{Al}, \mathrm{Fe}$, atau $\mathrm{Ca}$ ) yang mengikat $\mathrm{P}$ melalui ikatan hidroksil dan karboksil sehingga $\mathrm{P}$ tersebut tersedia bagi tanaman (Goldstein 1995; Kim et al. 1997). Bakteri selulolitik juga berperanan dalam merombak senyawa organik yang mengandung selulosa menjadi senyawa yang lebih sederhana sehingga dapat dimanfaatkan oleh tanaman.

Empat galur bakteri terpilih, yaitu BG003, BG010, BG011, dan BG013, berpotensi sebagai bakteri agens antagonis dan atau sekaligus sebagai pupuk hayati bagi pertanaman padi khususnya di lahan gambut atau pada ekologi sawah yang lain. Identifikasi empat galur potensial ini belum dilakukan. Liu et. el. (2019) melaporkan bakteri yang ditemukan pada tanah hutan gambut mencakup kelompok Proteobacteria (43.8\%), Acidobacteria (32.6\%), Actinobacteria (9.8\%), dan Planctomycetes (1.7\%).

Hasil penelitian ini dapat dijadikan sebagai bentuk kontribusi dalam pengembangan pertanian tanaman pangan, khususnya tanaman padi pada lahan gambut. Penelitian lanjut berbagai aspek terkait bakteri asal gambut masih perlu dilakukan untuk dikaji sebagai teknologi pendukung pengembangan lahan gambut menjadi persawahan.

\section{UCAPAN TERIMA KASIH}

Penulis mengucapkan terima kasih dan penghargaan atas kepercayaan yang diberikan oleh Zoological Society of London (ZSL)Indonesia Programme yang mendanai seluruh kegiatan penelitian dan publikasi melalui Perjanjian Jasa Konsultasi No. 220/CSA/ZSL/ $\mathrm{XI} / 2019$.

\section{DAFTAR PUSTAKA}

Goldstein AH. 1995. Recent progress in understanding the molecular genetics and biochemistry of calcium phosphate 
solubilisation by Gram-negative bacteria. Biol Agric Hort. 12:185-193. DOI: https:// doi.org/10.1080/01448765.1995.9754736.

Gupta P, Samant K, Sahu A. 2012. Isolation of cellulose-degrading bacteria and determination of their cellulolytic potential. Inter J Microbiol. 2012:1-5. DOI: https:// doi.org/10.1155/2012/578925.

Hoa PTP, Quang ND, Sakiyama Y, Hop DV, Hang DT, Ha TH, Van NT, Quy NTK, Da NTA. 2012. Sreening for actinomyces isolated from soil with the ability to inhibit Xanthomonas oryzae pv. oryzae causing rice blight disease in Vietnam. Afr $J$ Biotechnol. 11(80):14586-14594.

IRRI (International Rice Research Institute) 2014. Standard Evaluation System for Rice. 5th Ed. Los Banos (PH): INGER Genetic Resources Center. Hlm 55.

Karpagam T, Nagalakshmi PK. 2014. Isolation and characterization of phosphate solubilizing microbes from agricultural soil. Inter J Current Microbiol Appl Sci. 3(3):601-614.

Kifle MH, Laing MD. 2016. Isolation and screening of bacteria for their diazotrophic potential and their influence on growth promotion of maize seedlings in greenhouses. Frontiers Plant Sci. 6(1):18. DOI: http:10.3389/fpls.2015.01225.

Kim KY, Jordan D, Mc Donald GA. 1997. Solubilization of hydroxyl apatite by Enterobacter agglomerans and cloned Escherichia coli in culture medium. Biol Fertil Soils. 24:347-352. DOI: https:// doi.org/10.1007/s003740050256.

Liu B, Talukder MJH, Terhonen E, Lampella M, Vasander H, Sun H, Asiegbu F. 2019. The microbial diversity and structure in peatland forest in Indonesia. Soil Use Manage. 36:123-138. DOI: https://doi. org/10.1111/sum.1254.

Mace GM, Norris K, Fitter AH. 2012. Biodiversity and ecosystem services: a multilayered relationship. Trends Ecol Evol. 27:19-26. DOI: https://doi. org/10.1016/j.tree.2011.08.006.

Milagres AMF, Machuca A, Napoleao D. 1999.

Detection of siderophore production from several fungi and bacteria by a modification of chrome azurol S (CAS) agar plate assay. J Microbiol Methods. 37(1999):16. DOI: https://doi.org/10.1016/S01677012(99)00028-7.

Pankratov TA, Ivanova AO, Dedysh SN, Liesack W. 2011. Bacterial populations and environmental factors controlling cellulose degradation in an acidic sphagnum peat. Environ Microbiol. 13:1800-1814. DOI: https://doi.org/10.1111/j.14622920.2011.02491.x.

Pratiwi E, Satwika TD, Agus F. 2018. Keanekaragaman mikroba tanah gambut di bawah hutan dan di bawah perkebunan sawit di Provinsi Jambi. J Tanah Iklim 42:69-78. DOI: https://doi.org/10.21082/ jti.v42n1.2018.69-78.

Ritung S, Wahyunto, Nugroho K, Sukarman, Hikmatullah, Suparto, Tafakresnanto C. 2011. Peta Lahan Gambut Indonesia Skala 1:250.000. Bogor (ID): Balai Besar Penelitian dan Pengembangan Sumberdaya Lahan Pertanian.

Roselló-Mora R, Amann R. 2001. The species concept for prokaryotes. FEMS Microbiol Rev. 25:39-67. DOI: https://doi. org/10.1111/j.1574-6976.2001.tb00571.x.

Schaad W, Jones JB, Chun W. 2001. Laboratory Guide for Identification of Plant Pathogenic Bacteria, Third Edition. St Paul (US): APS Press.

Sorensen KW. 1993. Indonesian peat swamp forests and their role as a carbon sink. Chemosphere. 27:1065-1082. DOI: http://dx.doi.org/10.1016/00456535(93)90068-G.

Suparyono S, Suprihanto. 2004. Pathotype profile of Xanthomonas oryzae pv. oryzae isolates from the rice ecosystem in Java. Indones J Agric Sci. 5(2):6369. DOI: https://doi.org/10.21082/ijas. v5n2.2004.63-69.

UNDP. 2006. Malaysia's Peat Swamp Forest Conservation and Sustainable Use. Kualalumpur (MY): UNDP. 